\title{
A NEW ANTIBIOTIC, SETOMIMYCIN, PRODUCED BY A STRAIN OF STREPTOMYCES
}

\author{
Satoshi Ōmura, Haruo Tanaka, Yuzuru Iwai, Kazue Nishigaki, \\ Juichi Awaya, Yōko Takahashi and RoKurou Masuma \\ Kitasato University and The Kitasato Institute, \\ Shirokane 5-9-1, Minato-ku, Tokyo 108, Japan
}

(Received for publication August 2, 1978)

\begin{abstract}
A new antibiotic, setomimycin, was isolated from the culture broth of strain AM-2947, which was identified as Streptomyces pseudovenezuelae. The compound is a weakly acidic substance, and has UV-absorptions at 228, 268 and $422 \mathrm{~nm}$ and a molecular formula of $\mathrm{C}_{34} \mathrm{H}_{28} \mathrm{O}_{8}$ (MW 580). It is active against Gram-positive bacteria including Mycobacteria, and has antitumor activity against Sarcoma-180 solid tumor in mice.
\end{abstract}

In the course of our screening program for new antibiotics from actinomycetes, a new antibiotic, setomimycin, effective against Gram-positive bacteria including Mycobacteria and Sarcoma-180 solid tumor in mice, was obtained from the culture broth of an actinomycete (strain AM-2947) which had been isolated from a soil sample collected at Uchinomi-chō, Shōdo Island (The Setonai Sea), Japan. In the present paper, taxonomy of the producing strain, production, isolation, characterization and biological properties of the antibiotic are described.

\section{Characteristics of the Producing Strain}

\section{Morphological Characteristics}

The morphology of the strain cultured on yeast extract-malt extract agar or inorganic salts-starch agar was observed microscopically (Plates 1 and 2). The aerial mycelium was observed to be moderate on inorganic salts-starch and yeast extract-malt extract agars, but absent or poor on glucose-nitrate, peptone-yeast extract-iron, nutrient and glucose-peptone agars. It forms no whorls, but extends straight aerial hyphae. The spore chain is Rectus-flexibilis. The spores are elliptical or cylindrical $(0.4 \sim 0.8 \times 0.8 \sim 1.3 \mu)$. The spore surface is smooth.

Cultural and Physiological Characteristics

Strain AM-2947 was cultivated on various media described by WAKSMAN ${ }^{11}$ and International Streptomyces Project (ISP) ${ }^{2)}$ at $27^{\circ} \mathrm{C}$, and the changes of growth, aerial mycelium and soluble pigment were observed after periods of 7, 14 and 21 days. Utilization of carbon sources was tested by growth on Pridham and Gottlieb's medium ${ }^{2)}$ containing $1 \%$ of various carbon sources. Color names and hue numbers indicated in Tables 1 and 4 were those of the Color Harmony Manual (4th edition) ${ }^{3 !}$.

The cultural and physiological characteristics of strain AM-2947 are listed in Tables 1 and 2, respectively. The utilization of carbon sources by the strain is shown in Table 3. The cultural characteristics can be summarized as follows: growth is moderate or good, and is pale yellow to pale yellowish brown; aerial mass color is brownish gray to brownish white; soluble pigment is yellow brownish white; melanoid pigment is produced. A cell wall preparation of the strain was found to contain LL-diaminopimelic acid and glycine but no meso-diaminopimelic acid. 
Plate 1. Photomicrograph of the sporophores of strain AM-2947

Yeast extract-malt extract agar, $27^{\circ} \mathrm{C}, 1$ week.

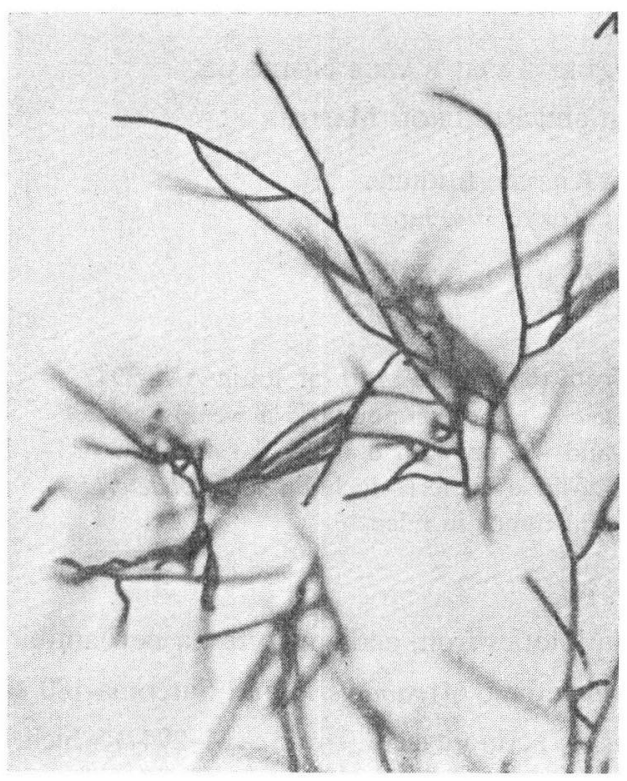

Plate 2. Electronmicrograph of the spores of strain AM-2947

Inorganic salts-starch agar, $27^{\circ} \mathrm{C}, 2$ weeks.

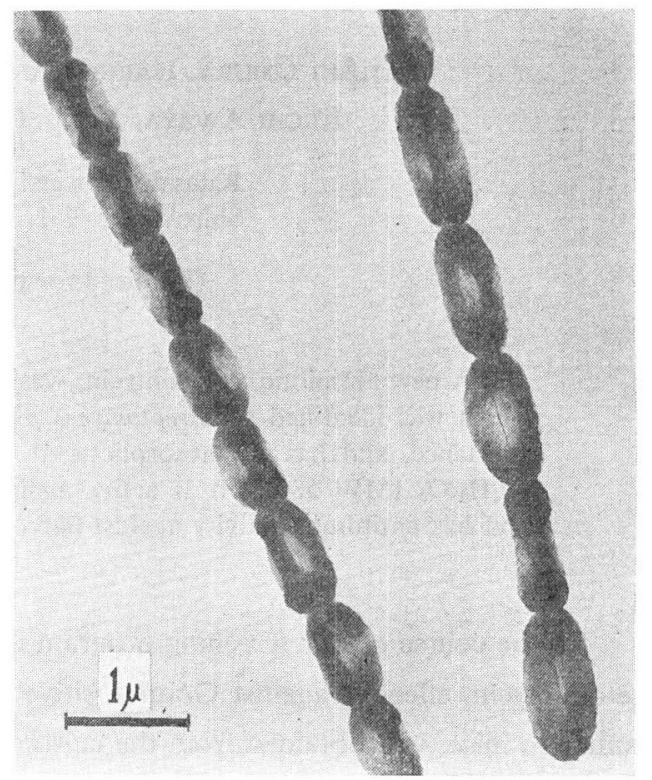

Table 1. Cultural characteristics of strain AM-2947

\begin{tabular}{|c|c|c|c|}
\hline Medium & Growth & Aerial mycelium & Soluble pigment \\
\hline Sucrose-nitrate agar & moderate, gold (21c) & $\begin{array}{l}\text { abundant, velvety } \\
\text { cream }\left(1 \frac{1}{2} \mathrm{ca}\right)\end{array}$ & none \\
\hline Glucose-nitrate agar & $\begin{array}{l}\text { moderate, wrinkled } \\
\text { light maize (2ea) }\end{array}$ & none & none \\
\hline $\begin{array}{l}\text { Glycerol-calcium } \\
\text { malate agar }\end{array}$ & $\begin{array}{l}\text { moderate } \\
\text { dull gold }(2 n g)\end{array}$ & $\begin{array}{l}\text { moderate, cottony } \\
\text { light antique gold } \\
\left(1 \frac{1}{2} \mathrm{ic}\right)\end{array}$ & antique gold $\left(1 \frac{1}{2} l e\right)$ \\
\hline $\begin{array}{l}\text { Glucose-asparagine } \\
\text { agar (ISP) }\end{array}$ & $\begin{array}{l}\text { moderate } \\
\text { mustard gold ( } 2 \text { ne) }\end{array}$ & $\begin{array}{l}\text { moderate, velvety } \\
\text { light ivory ( } 2 \mathrm{ca})\end{array}$ & $\begin{array}{l}\text { poor } \\
\text { light antique gold }\left(1 \frac{1}{2} \mathrm{ic}\right)\end{array}$ \\
\hline $\begin{array}{l}\text { Glycerol-asparagine } \\
\text { agar (ISP) }\end{array}$ & $\begin{array}{l}\text { abundant, wrinkled } \\
\text { yellow maple (3ng) }\end{array}$ & $\begin{array}{l}\text { partially, velvety } \\
\text { oyster white (b) }\end{array}$ & none \\
\hline $\begin{array}{l}\text { Inorganic salts- } \\
\text { starch agar (ISP) }\end{array}$ & $\begin{array}{l}\text { moderate, bamboo } \\
(2 \mathrm{gc})\end{array}$ & $\begin{array}{l}\text { moderate, velvety } \\
\text { covert gray }(2 \mathrm{fe})\end{array}$ & none \\
\hline Tyrosine agar (ISP) & $\begin{array}{l}\text { moderate } \\
\text { dark brown (3pn) }\end{array}$ & $\begin{array}{l}\text { moderate, velvety } \\
\text { natural ( } 3 \mathrm{dc})\end{array}$ & dark brown $(3 \mathrm{nl})$ \\
\hline Nutrient agar & moderate, camel (3ie) & poor, white (a) & yellow maple (3ng) \\
\hline $\begin{array}{l}\text { Glucose-peptone } \\
\text { agar }\end{array}$ & $\begin{array}{l}\text { moderate, wrinkled } \\
\text { mustard brown }(2 n i)\end{array}$ & none & poor, topaz (3ne) \\
\hline $\begin{array}{l}\text { Yeast extract-malt } \\
\text { extract agar (ISP) }\end{array}$ & $\begin{array}{l}\text { moderate, wrinkled } \\
\text { natural }(2 \mathrm{dc})\end{array}$ & $\begin{array}{l}\text { moderate, velvety } \\
\text { sand }(3 \mathrm{cb})\end{array}$ & poor, cinnamon (31e) \\
\hline Oatmeal agar (ISP) & $\begin{array}{l}\text { moderate, honey gold } \\
\text { (2ic) }\end{array}$ & $\begin{array}{l}\text { abundant, cottony } \\
\text { pussywillow gray }(5 \mathrm{dc})\end{array}$ & honey gold ( $2 \mathrm{ic}$ ) \\
\hline $\begin{array}{l}\text { Peptone-yeast extract } \\
\text { agar (ISP) }\end{array}$ & $\begin{array}{l}\text { abundant, wrinkled } \\
\text { yellow maple (3ng) }\end{array}$ & $\begin{array}{l}\text { partially, velvety } \\
\text { oyster white (b) }\end{array}$ & none \\
\hline
\end{tabular}


Table 2. Physiological characteristics of strain AM-2947

\begin{tabular}{l|c}
\hline Melanin formation & + \\
Tyrosinase reaction & + \\
$\mathrm{H}_{2} \mathrm{~S}$ production & + \\
Nitrate reduction & - \\
Liquefaction of gelatin & - \\
Peptonization of milk & + \\
Coagulation of milk & - \\
Hydrolysis of starch & + \\
Cellulolytic activity & - \\
Temperature range for growth & $20 \sim 38^{\circ} \mathrm{C}$ \\
\hline
\end{tabular}

Table 3. The utilization of carbon sources by strain AM-2947

\begin{tabular}{l|c}
\hline Carbon source & Response \\
\hline D-Glucose & + \\
L-Arabinose & + \\
D-Xylose & + \\
D-Fructose & + \\
L-Rhamnose & + \\
i-Inositol & + \\
D-Mannitol & + \\
Sucrose & + \\
Raffinose & + \\
\hline
\end{tabular}

Table 4. Comparison of strain AM-2947 with Streptomyces pseudovenezuelae ISP 5215

\begin{tabular}{|c|c|c|}
\hline & Strain AM-2947 & $\begin{array}{c}\text { S. pseudovenezuelae } \\
\text { ISP 5215 }\end{array}$ \\
\hline Morphology & Rectus-flexibilis, smooth & Rectus-flexibilis, smooth \\
\hline $\begin{array}{l}\text { Cultural characteristics } \\
\text { 1) Inorganic salts-starch agar } \\
\qquad \mathrm{GM}^{*} \\
\mathrm{SP}^{*}\end{array}$ & $\begin{array}{l}\text { bamboo }(2 \mathrm{gc}) \\
\text { cottony, covert gray }(2 \mathrm{fe}) \\
\text { none }\end{array}$ & $\begin{array}{l}\text { bamboo }(2 \mathrm{gc}) \\
\text { cottony, light gray }(\mathrm{c}) \\
\text { none }\end{array}$ \\
\hline $\begin{array}{l}\text { 2) Glycerol-asparagine agar } \\
\qquad \mathrm{G} \\
\mathrm{AM}\end{array}$ & $\begin{array}{l}\text { yellow maple ( } 3 \mathrm{ng}) \\
\text { velvety, oyster white (b) } \\
\text { none }\end{array}$ & $\begin{array}{l}\text { biscuit (2ec) } \\
\text { velvety, light gray (c) } \\
\text { none }\end{array}$ \\
\hline $\begin{array}{l}\text { 3) Glucose-asparagine agar } \\
\text { GM } \\
\text { SP }\end{array}$ & $\begin{array}{l}\text { mustard gold ( } 2 \mathrm{ne}) \\
\text { velvety, light ivory }(2 \mathrm{ca}) \\
\text { poor }\end{array}$ & $\begin{array}{l}\text { mustard gold ( } 2 \mathrm{ne}) \\
\text { velvety, silver gray ( } 3 \mathrm{fe}) \\
\text { very poor }\end{array}$ \\
\hline Production of the antibiotic & + & - \\
\hline
\end{tabular}

* G, growth; AM, aerial mycelium; SP, soluble pigment.

From the above results, the strain is chromogenic and belongs to the gray or red series of the genus Streptomyces classified by PridHAM and TRESNER ${ }^{4)}$. Among known Streptomyces species described in "Bergey's Manual of Determinative Bacteriology", 8th ed.," "The Actinomycetes", Vol. II by WAKSMAN ${ }^{11}$ and ISP reports by SHIRLING and GoTtLIEB ${ }^{5 \sim 8)}$, Streptomyces pseudovenezuelae ${ }^{61}$ is closely related to strain AM-2947. In comparison of strain AM-2947 with S. pseudovenezuelae ISP 5212, all of the morphological and physiological characteristics and almost all of the cultural characteristics of the former were in agreement with those of the latter. As shown in Table 4, in some cultural characteristics only a little difference is recognized. Strain AM-2947 produces setomimycin, but strain ISP 5212 does not.

Therefore, strain AM-2947 should be identified as S. pseudovenezuelae, and was designated as S. pseudovenezuelae strain AM-2947. The strain has been deposited at the Fermentation Research Institute, Agency of Industrial Science and Technology, Chiba, Japan, with the acession number FERM-P No. 3430, and at United States Department of Agriculture, Agricultural Research Service, Northern Regional Research Center (Peoria, Illinois 61604) with the acession number NRRL 11269. 


\section{Production of Setomimycin}

The stock culture of strain AM-2947 ( $S$. pseudovenezuelae) was maintained as an agar slant (KRAINSKY's agar medium). A 7-day culture of the agar slant was incubated into a seed medium $(100 \mathrm{ml})$ in a 500-ml Sakaguchi flask and incubated for 2 days at $27^{\circ} \mathrm{C}$. The seed culture $(200 \mathrm{ml})$ was transferred into 20 liters of a production medium in a 30-liter jar fermentor and incubated for 2 days at $27^{\circ} \mathrm{C}$ (agitation, $300 \mathrm{rpm}$; aeration, 10 liters per minute). The composition of the seed and production media was $2.0 \%$ glycerol, $2.0 \%$ soybean meal and $0.3 \%$ sodium chloride (the $\mathrm{pH}$ was adjusted to 7.0 with $6 \mathrm{~N}$ sodium hydroxide before sterilization). In the incubation using a jar fermentor, Adekanol LG-109 (Asahi ElectroChemical Co., Ltd.) was used as an antifoam agent. The antibiotic activity of the culture broth was assayed by the paper disc method using Bacillus subtilis PCI 219 as a test organism.

A typical time course of the fermentation is shown in Fig. 1. The antibiotic production started one day after the inoculation and reached the maximum at the 2 nd day. The amount of the antibiotic accumulated was about $150 \mu \mathrm{g} / \mathrm{ml}$.

\section{Isolation of Setomimycin and Preparation of its Acetate}

Culture broth (20 liters) of $S$. pseudovenezuelae strain AM-2947, obtained by incubation in a 30-liter jar fermentor, was used as a starting material for the isolation of the antibiotic. The

Table 5. Physicochemical properties of setomimycin and its diacetate

\begin{tabular}{|c|c|c|}
\hline & Setomimycin & Setomimycin diacetate \\
\hline Nature & reddish orange powder & yellow powder \\
\hline $\mathrm{mp}\left({ }^{\circ} \mathrm{C}\right)$ & $176 \sim 178^{\circ}$ & $185 \sim 187^{\circ}$ \\
\hline$[\alpha]_{D}^{24}$ & $+502^{\circ}\left(\right.$ c $\left.1.0, \mathrm{CHCl}_{3}\right)$ & $+392^{\circ}\left(c 1.0, \mathrm{CHCl}_{3}\right)$ \\
\hline $\begin{array}{l}\text { Anal. } \\
\qquad \begin{array}{c}\mathrm{C} \% \\
\mathrm{H} \\
\mathrm{N}\end{array}\end{array}$ & $\begin{array}{ll}\text { Found } & \text { Calcd. } \\
69.88 & 70.34 \\
5.09 & 4.86 \\
0 & 0\end{array}$ & $\begin{array}{cc}\text { Found } & \text { Calcd. } \\
68.80 & 68.67 \\
5.07 & 4.85 \\
0 & 0\end{array}$ \\
\hline Formula & $\mathrm{C}_{34} \mathrm{H}_{28} \mathrm{O}_{9}(\mathrm{MW} \mathrm{580)}$ & $\mathrm{C}_{38} \mathrm{H}_{32} \mathrm{O}_{11}(\mathrm{MW} 664)$ \\
\hline EI-MS & & $664\left(\mathrm{M}^{+}\right), 622\left(\mathrm{M}^{+}-42\right), 580\left(\mathrm{M}^{+}-84\right)$ \\
\hline FD-MS & $581\left(\mathrm{M}^{+}+1\right)$ & \\
\hline $\mathrm{UV} \lambda_{\max }^{\mathrm{MeOH}} \mathrm{nm}(\varepsilon)$ & $\begin{array}{l}228(49,400), 268(42,500) \\
422(13,600)\end{array}$ & $\begin{array}{l}225(57,100), 266(40,800) \\
385 \sim 395(10,300)\end{array}$ \\
\hline $\mathrm{IR} \nu_{\max }^{\mathrm{KBr}}\left(\mathrm{cm}^{-1}\right)$ & 1690,1580 & $1760,1720,1700,1610,1580$ \\
\hline
\end{tabular}

Fig. 1. A typical time course of setomimycin proThe medium and culture conditions are in the text.

Fig. 2. UV-absorption spectra of setomimycin

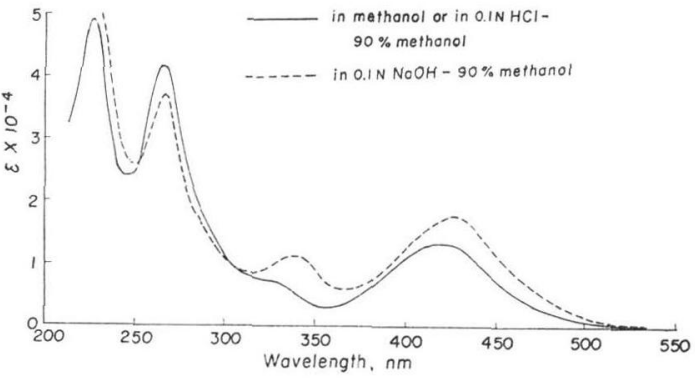

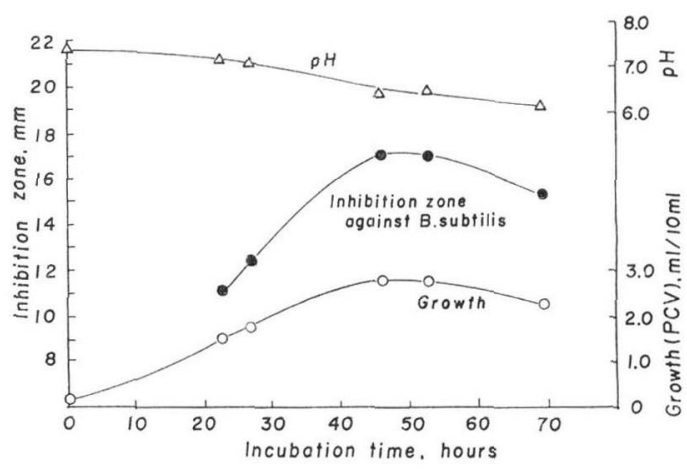


Fig. 3. IR spectrum of setomimycin ( $\mathrm{KBr}$ method)

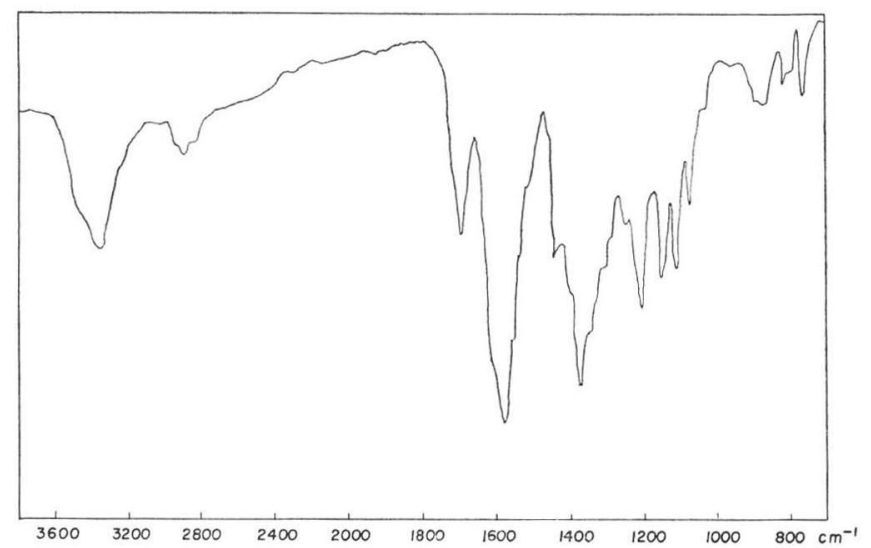

Fig. 4. PMR spectrum of setomimycin in $\mathrm{CDCl}_{3}$

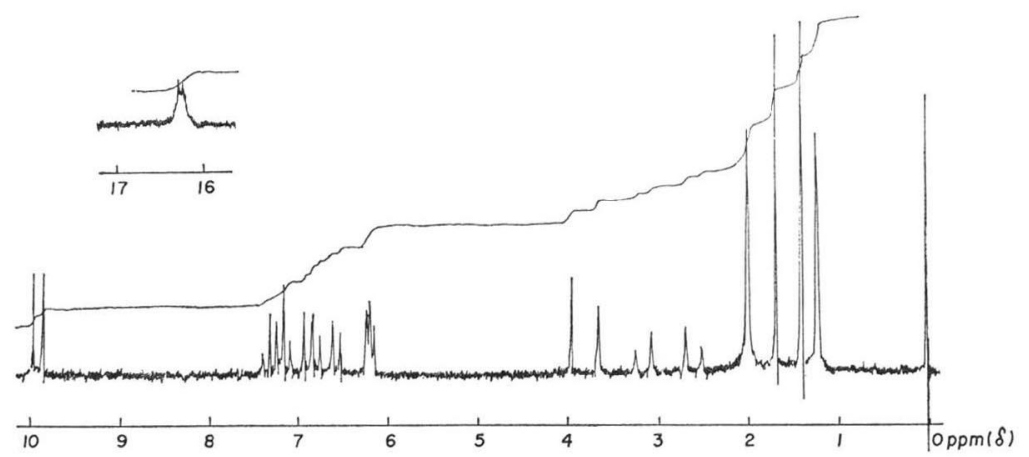

Fig. 5. $\mathrm{CMR}$ spectrum of setomimycin in $\mathrm{CDCl}_{3}$

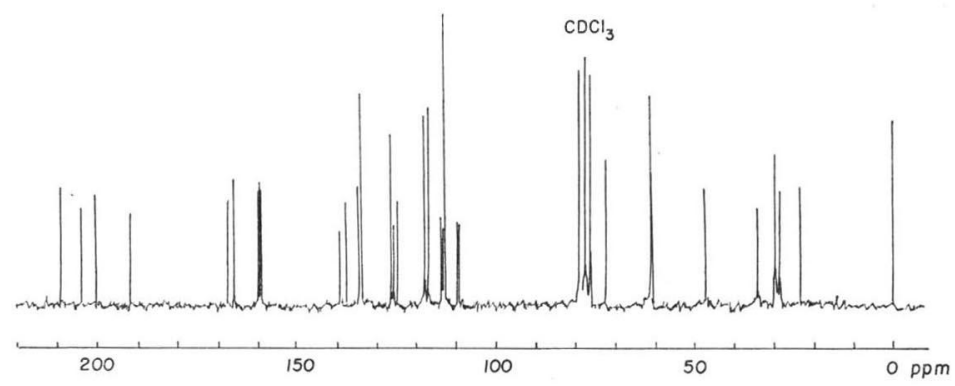

antibiotic was detected by the antimicrobial activity against Bacillus subtilis PCI 219 and silica gel thinlayer chromatography. After the $\mathrm{pH}$ value of the culture broth was adjusted to 2.0 with $6 \mathrm{~N}$ hydrochloric acid, ethyl acetate (10 liters) was added to the culture broth containing the mycelia, stirred vigorously, and centrifuged to give the ethyl acetate layer. After the ethyl acetate layer was concentrated under reduced pressure, it was applied on an acid-treated silica gel column $(250 \mathrm{~g})$ and then developed with chloroform and methanol (200:1). The active eluate from the column was evaporated under reduced pressure to give a reddish orange powder $(2.34 \mathrm{~g})$. The powder was further purified 
Table 6. The microbial spectra of setomimycin and its acetate

\begin{tabular}{|c|c|c|c|}
\hline \multirow{2}{*}{ Test organisms } & \multirow{2}{*}{ Medium*1 } & \multicolumn{2}{|c|}{$\operatorname{MIC}(\mu \mathrm{g} / \mathrm{ml})^{* 2}$} \\
\hline & & Setomimycin & $\begin{array}{c}\text { Setomimycin } \\
\text { acetate }\end{array}$ \\
\hline Staphylococcus aureus FDA 209P & $\begin{array}{l}\mathrm{N} \\
\mathrm{H}\end{array}$ & $\frac{3.13}{25}$ & 25 \\
\hline S. aureus FS 1277 (PC-R*3) & $\begin{array}{l}\mathrm{N} \\
\mathrm{H}\end{array}$ & $\begin{array}{l}3.13 \\
12.5\end{array}$ & 12.5 \\
\hline S. aureus $\mathrm{KB} 64$ (EM, TC- $\mathrm{R}^{* 3}$ ) & $\begin{array}{l}\mathrm{N} \\
\mathrm{H}\end{array}$ & $\begin{array}{l}3.13 \\
12.5\end{array}$ & 12.5 \\
\hline Bacillus subtilis PCI 219 & $\begin{array}{l}\mathrm{N} \\
\mathrm{H}\end{array}$ & $\begin{array}{l}3.13 \\
6.25\end{array}$ & 6.25 \\
\hline B. cereus $\mathrm{T}$ & $\begin{array}{l}\mathrm{N} \\
\mathrm{H}\end{array}$ & $\begin{array}{l}3.13 \\
6.25\end{array}$ & 6.25 \\
\hline Sarcina lutea PCI 1001 & $\begin{array}{l}\mathrm{N} \\
\mathrm{H}\end{array}$ & $\begin{array}{l}3.13 \\
6.25\end{array}$ & 100 \\
\hline Mycobacterium smegmatis ATCC 607 & $\begin{array}{l}\mathrm{N} \\
\mathrm{H}\end{array}$ & $\begin{array}{l}1.56 \\
6.25\end{array}$ & 1.56 \\
\hline Nocardia asteroides KB 49 & $\begin{array}{l}\mathrm{N} \\
\mathrm{H}\end{array}$ & $\begin{array}{l}1.56 \\
3.13\end{array}$ & 12.5 \\
\hline Proteus vulgaris IFO 3167 & $\begin{array}{l}\mathrm{N} \\
\mathrm{H}\end{array}$ & $\begin{array}{l}>100 \\
>100\end{array}$ & $>100$ \\
\hline Escherichia coli $\mathrm{NIHJ}$ & $\begin{array}{l}\mathrm{N} \\
\mathrm{H}\end{array}$ & $\begin{array}{l}>100 \\
>100\end{array}$ & $>100$ \\
\hline Salmonella typhimurium KB 20 & $\begin{array}{l}\mathrm{N} \\
\mathrm{H}\end{array}$ & $\begin{array}{r}100 \\
>100\end{array}$ & $>100$ \\
\hline Shigella sonnei E 33 & $\begin{array}{l}\mathrm{N} \\
\mathrm{H}\end{array}$ & $\begin{array}{l}>100 \\
>100\end{array}$ & $>100$ \\
\hline Pseudomonas aeruginosa $\mathrm{P}-3$ & $\begin{array}{l}\mathrm{N} \\
\mathrm{H}\end{array}$ & $\begin{array}{l}>100 \\
>100\end{array}$ & $>100$ \\
\hline Candida albicans & $\mathbf{P}$ & $>100$ & \\
\hline Saccharomyces sake & $\mathbf{P}$ & $>100$ & \\
\hline Aspergillus niger & $\mathbf{P}$ & $>100$ & \\
\hline Piricularia oryzae & $\mathbf{P}$ & 50 & \\
\hline Microsporum gypseum & $\mathbf{P}$ & $>100$ & \\
\hline Trichophyton interdigitale & $\mathbf{P}$ & $>100$ & \\
\hline T. rubrum & $\mathbf{P}$ & $>100$ & \\
\hline
\end{tabular}

$* 1 \mathrm{~N}$, nutrient agar $\left(37^{\circ} \mathrm{C}, 24\right.$ hours $) ; \mathrm{H}$, heart infusion agar $\left(37^{\circ} \mathrm{C}, 24\right.$ hours $) ; \mathrm{P}$, potato agar $\left(27^{\circ} \mathrm{C}\right.$, 72 hours).

*2 Minimum inhibitory concentration determined by agar dilution method.

*3 PC, penicillin; EM, erythromycin; TC, tetracycline; R, resistant.

by preparative thin-layer chromatography on silica gel (Merck's plate, thickness: $2 \mathrm{~mm}$ ) with chloroform and methanol $(10: 1)$. The $\mathrm{Rf}$ value with the system is 0.52 . The $\mathrm{Rf}$ values of the antibiotic on thin-layer chromatography with chloroform - methanol $(5: 1)$, benzene - acetone $(4: 1)$, benzene ethyl acetate $(1: 3)$ and benzene - methanol (4:1) were $0.59,0.18,0.37$ and 0.31 , respectively.

The preparation of an acetate of the antibiotic was performed as follows. The pure powder of the antibiotic $(200 \mathrm{mg}$ ) was dissolved in acetic anhydride $(4 \mathrm{ml})$ and pyridine $(5 \mathrm{ml})$ was added to the solution. After standing the mixture in room temperature for 40 minutes, 2 volumes of ethyl acetate were added to the solution together with some ice. The ethyl acetate layer was washed with water, concentrated under reduced pressure, and then applied on preparative thin-layer chromatography on silica gel with benzene and acetone (3:1) to give a yellow powder (148 mg). The Rf value of the acetate on the chromatogram was 0.48 . 
Physicochemical Properties of Setomimycin and its Acetate

The antibiotic, setomimycin, obtained as described above is weakly acidic in nature and is soluble in lower alcohols, lower alkyl acetates, acetone, chloroform and benzene, but insoluble in water, petroleum ether and $n$-hexane. The compound is positive to ferric chloride and ferric hydroxamate, but negative to ninhydrin, RYDONSMITH and EHRLich reagents. It contains no nitrogen and no halogen. The other physicochemical properties of setomimycin and its acetate are listed in Table 5. The UV, IR, PMR and CMR spectra of setomimycin are given in Figs. $2 \sim 5$.

The UV absorptions of setomimycin (Fig. 2) show that it has a naphthocyclinone or anthracyclinone skeleton as a chromophore. The CMR and PMR spectra (Figs. 5 and 4) suggest that the compound contains 34 carbons and 28 protons: 12 protons from 4 methyl groups, 4 protons from two methine groups and a methylene group, 8 protons from olefinic and/or aromatic moieties, and 4 protons from 4 hydroxyl groups. It contains no sugar moiety. In the PMR spectrum of the acetate (Fig. 6) the signals of 2 hydroxyl groups disappeared and those of two additional acetyl groups (2.46 and $2.49 \mathrm{ppm})$ appeared. This shows that the acetate is a diacetyl derivative of setomimycin. The MS-fragmentation of the acetate $\left[m / e 664\left(\mathrm{M}^{+}\right), 622\left(\mathrm{M}^{+}-42\right), 580\left(\mathrm{M}^{+}-84\right)\right]$ and the IR absorptions (1760 and $1720 \mathrm{~cm}^{-1}$ ) also support this. From the data of PMR, CMR and MSspectra of setomimycin and its acetate, their formulae are shown to be $\mathrm{C}_{34} \mathrm{H}_{28} \mathrm{O}_{9}$ (MW 580) and $\mathrm{C}_{38} \mathrm{H}_{32} \mathrm{O}_{11}$ (MW 664), respectively.

Fig. 6. PMR spectrum of diacetylsetomimycin in $\mathrm{CDCl}_{3}$

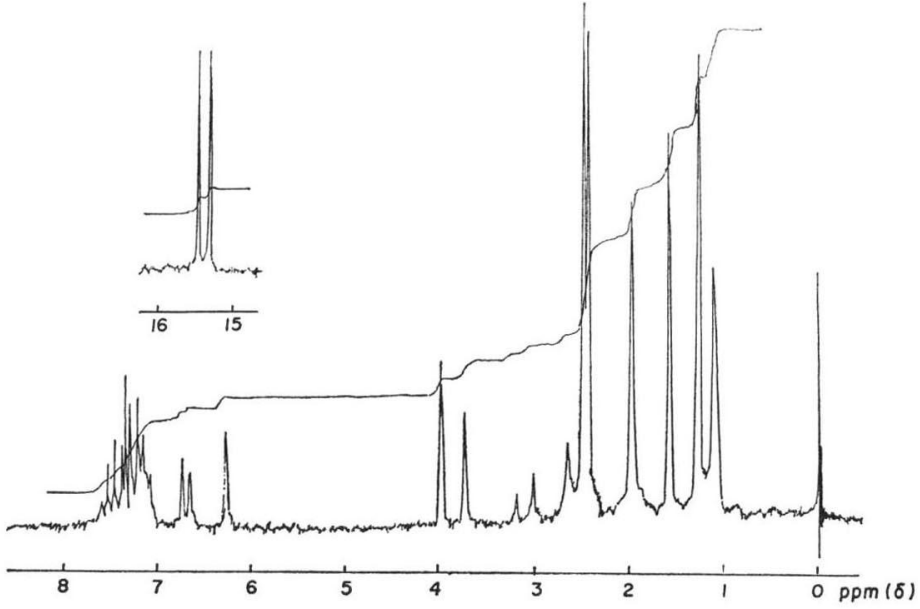




\section{Biological Properties of Setomimycin and its Diacetate}

The antimicrobial activities of setomimycin and its diacetate were determined by the conventional agar dilution method using nutrient and heart infusion agars $\left(37^{\circ} \mathrm{C}, 24\right.$ hours). As shown in Table 6, the antibiotic and its diacetate inhibited Gram-positive bacteria including Mycobacteria. But they are scarcely active against Gram-negative bacteria and fungi. The acute toxicity $\left(\mathrm{LD}_{50}\right.$, iv) of setomimycin is $60 \mathrm{mg} / \mathrm{kg}$ in mice.

Setomimycin exhibits antitumor activity against Sarcoma-180 solid tumor on ddY mice. As shown in Table 7, when $200 \mathrm{mg} / \mathrm{kg}$ of setomimycin was injected intraperitoneally once at 1 day after transplantation of tumor, the tumor size (treated/control) at the 7th day after administration was 0.43 .

\section{Discussion}

From the above results, the antibiotic, setomimycin, isolated from the culture broth of $S$. pseudovenezuelae strain AM-2947, was found to be an antibiotic active against Gram-positive bacteria including Mycobacteria and Sarcoma-180 solid tumor. It was also found to have a naphthocyclinone or anthracyclinone chromophore but no sugar and no nitrogen. Among known antibiotics, nanaomycin $\mathrm{A}^{9,10)}$ and griseusins ${ }^{11)}$ show some resemblance to setomimycin in respect to UV absorptions in methanol. However, these antibiotics are different from setomimycin in molecular weight, melting point, UV spectrum in an alkaline solution, and so on.

Therefore, the antibiotic, setomimycin, was concluded to be a new antibiotic. Further investigations on its chemical structure are in progress.

\section{Acknowledgements}

We wish to thank Dr. T. HiguCHI (JEOL) for FD-mass spectrometry and Mr. S. ŌKUBo (Kyowa Hakko Kogyo Co., Ltd.) for assays of antitumor activity and $\mathrm{LD}_{50}$. Thanks are also due to Mr. H. MryashitA and Miss Y. UCHIYAma for their helpful assistance.

This work was partially supported by a fund from Japan Keirin Association.

\section{References}

1) Waksman, S. A.: The actinomycetes. Vol. II. The Williams \& Wilkins Co., Baltimore, 1961

2) Shirling, E. B. \& D. Gottlieb: Methods for characterization of Streptomyces species. Int. J. Syst. Bacteriol. 16: 313 340, 1966

3) Container Corporation of America: Color Harmony Manual. 4th edition. Chicago, U.S.A., 1958

4) Pridham, T. G. \& H. D. Tresner: Bergey's Manual of Determinative Bacteriology. 8th ed., The Williams \& Wilkins Co., Baltimore, pp. 748 829, 1974

5) Shirling, E. B. \& D. Gottlieb: Cooperative description of type strains of Streptomyces. II. Species descriptions from first study. Int. J. Syst. Bacteriol. 18: 69 189, 1968

6) Shirling, E. B. \& D. Gottlieb: Cooperative description of type strains of Streptomyces. III. Additional species descriptions from first and second studies. Int. J. Syst. Bacteriol. 18: 279 392, 1969

7) Shirling, E. B. \& D. Gottlieb: Cooperative description of type cultures of Streptomyces. IV. Species description from the second, third and fourth studies. Int. J. Syst. Bacteriol. 19: 391 512, 1969

8) Shirling, E. B. \& D. Gottlieb: Cooperative description of type cultures of Streptomyces. V. Additional description. Int. J. Syst. Bacteriol. 22: 265 394, 1972

9) Ōmura, S.; H. Tanaka, Y. Koyama, R. Öiwa, M. Katagiri, J. Awaya, T. Nagai \& T. Hata: Nanaomycins A and B, new antibiotics produced by a strain of Streptomyces. J. Antibiotics 27: 363 365, 1974

10) Tanaka, H.; Y. Koyama, J. Awaya, H. Marumo, R. Ōiwa, M. Katagiri, T. Nagai \& S. Ōmura: Nanaomycins, new antibiotics produced by a strain of Streptomyces. I. Taxonomy, isolation, characterization and biological properties. J. Antibiotics 28: 860 867, 1975

11) Tsuj, N.; M. Kobayashi, Y. Wakisaka, Y. Kawamura, M. Mayama \& K. Matsumoto: New antibiotics, griseusins A and B. Isolation and characterization. J. Antibiotics 29: 7 9, 1976 